\title{
Chinese Engagement in Sub-Saharan Africa: Can the Beijing Consensus be Explained Under World-Systems Analysis?
}

\author{
Ewelina Róża Lubieniecka
}

Received: 16 October 2013/Accepted: 15 January 2014/Published online: 17 July 2014

(C) The Author(s) 2014. This article is published with open access at Springerlink.com

\begin{abstract}
The purpose of this paper is to: (1) explain what the historical origins of the world-systems concept are; (2) present the background for building the Washington Consensus; (3) attempt to answer if the Beijing Consensus can be interpreted as an alternative to the Washington Consensus; (4) attempt to answer if the worldsystems concept is applicable to the current engagement of China in Africa. The world-systems concept provides a useful framework for research in international relations, thanks to both its methodological and theoretical assumptions. As it urges for treating social sciences as an interconnected system, i.e. it believes there is a link between sociology, economics, anthropology and the political sciences, it enables studying the reality of current international relations. Chinese presence in SubSaharan Africa should be seen from different points of view, as it affects most spheres of the state: it influences the economics and societies of the African countries (e.g. employment, migration, environment), as well as politics (e.g. elections in Zambia in 2011 BBC http://www.bbc.co.uk/news/world-africa14952240, 2011). Thus, the multi-dimensional analysis provided by the worldsystems theory, though not free of drawbacks (e.g. lack of a detailed analysis of each variable), allows a comprehensive and holistic look at the issue of Chinese engagement in Africa. In terms of theoretical assumptions, its focus on system as a whole (which can be both studied at domestic and international levels) provides a basis for conducting studies at a regional level, treating Sub-Saharan Africa as the study's object. The classic world-systems concept defines world economy as driven by the cores' domination on the peripheries (described also as North-South division). Most countries in sub-Saharan Africa fit into the scheme of world-systems analysis as the peripheries, but China cannot be treated as a core state: it is a semiperiphery, as described by Wallerstein, and representative of Global South. China's
\end{abstract}

E. R. Lubieniecka $(\bowtie)$

Institute of International Relations, Section of Non-European Area Studies,

University of Warsaw, Ul. Żurawia 4, 00-503 Warsaw, Poland

e-mail: ewelinalubieniecka@gmail.com 
policy towards Sub-Saharan African countries has a distinct geo-economic pattern-a pattern of South-South cooperation. China's relations with Sub-Saharan Africa are (at least on the rhetoric sphere) built on 'mutual benefit', 'win-win cooperation', and similar historical experience, though the partners are not on a similar level of economic development. The growing presence of China in Africa is, therefore, a challenge to traditional assumptions of world-systems analysis and should be further researched. The aim of this article is to answer whether the worldsystems theory can be reinterpreted to serve as the framework for conducting research on Chinese engagement in the Global South, especially in Sub-Saharan African countries. The Washington Consensus regarded as the general shift from Keynesianism to neoliberal economic policies (i.e. in the broader sense than that given by Williamson in 1989) fits into the dialectic of world-systems analysis. The Washington Consensus principles provide a framework through which the core countries carry out their policies towards the peripheries. However, not only numerous scholars (Broad and Cavanagh World Policy Journal 16:79, 1999; Wallerstein Shall We Discuss Poverty?, 2010; Rodrik Journal of Economic Literature XLIV:973, 2006) but also politicians (As the former British Prime Minister Gordon Brown Washington Post 2009) declared the death of the Washington Consensus. It became even more apparent after the latest financial crisis. Joshua Ramo coined the term "the Beijing Consensus" to describe the Chinese model of cooperation, different from the Western. Is this distinction based on a reliable foundation? Is the Beijing Consensus an alternative to the Washington Consensus? Can the current unprecedented presence of China in Sub-Saharan Africa (as well as in other regions of the Global South) be seen as a part of the world-systems concept? Should the China-Africa relationship be the new direction of research in the world-systems concept?

Keywords World-systems · Dependency theory · Beijing consensus · Washington consensus · China · Africa

\section{The World-Systems Concept: Its Origins and Historical Background}

Dependency theory is, within the French Annales school (Fernand Braudel) and Marxian works, one of the major intellectual blocks of Immanuel Wallerstein's world-systems theory (Wallerstein 2004a, p. 10, c, p. 10). However, there are some points in which the world-systems analysis differs from dependency theory. The major differences are: the unit of analysis (in dependency theory, it is the nationstate; for world-systems analysis, it is the world as a whole) and bimodal versus trimodal world structure (the world-systems theory adds a semi-periphery category to core-periphery distinction assumed by the dependency theorists). However, similarities are omnipresent; Wallerstein was highly influenced by neo-Marxism especially as represented by Andre Frank and Samir Amin. Basic categories in the world-systems analysis such as unequal exchange and core-periphery division of the world have been drawn from dependency theory (So 1990, pp. 171-172). Thus, 
knowing the background of the dependency theory is crucial for understanding the world-systems analysis.

Dependency theory was an expression of opposition to the Enlightenment tradition that grew out of the 'Modernization theory', which was based on belief in the gradual, unidirectional growth model for social change. Proponents of 'Modernization theory' (similar in tone, as evolution in sociology) recognize development as a historical process, in which the state now 'undeveloped' or 'underdeveloped' has to go through the same process by which the 'developed' states already have. 'Modernization theory' does not take into account that the path may be different, as the historical, cultural, and economic background of every state differs (Ferraro 2008, pp. 58-64).

The 1960s were the heyday of dependency theory due to Raul Prebisch, Argentinean economist and diplomat. Prebisch was not only involved in the creation of the Argentinean statistics office and the central bank, but also took part in negotiations, when in the 1930s Argentina's economy collapsed due to a drop in demand in the United Kingdom for Argentinean corn and meat. Prebisch is also famous for his thesis (parallel conclusions were drawn by Hans Singer, an economist associated with the United Nations), according to which the price of basic products tends to decline relatively to manufactured goods and, therefore, that industrialized countries have more gains from trade than unindustrialized ones, which leads to a widening gap between them.

Prebisch was an important figure in the international economic arena since the late 1940s. He was constantly and strongly present in the United Nations structures (first as Chairman of the Economic Commission for Latin America-ECLA, then as Director of the United Nations Conference on Trade and DevelopmentUNCTAD). Prebisch is considered to be one of the first structuralists (next to WA Lewis; Kociszewski 2011, p. 62). He assumed that the bad state of economy in Latin America was structure-based, i.e. it resulted from the structure, and that the foundations of international economic relations were based on dependence. According to neo-classical economics, international trade should lead to the prosperity of all participants in the exchange (Pareto optimum), although it is not necessarily profitable in the same way for all parties.

Price volatility of raw materials (which were the main source of income from export of Third World countries ${ }^{1}$ ) on the international market prevented the stable development of the countries exporting them. Because of that, developing countries were dependent on the commercial policies pursued by developed states. The organization of the economies of the periphery is subject to the needs of the centre, and the centre manipulates the international market to make the value of its processed products higher (Hryniewicz 2010, p. 6). Export drives the economy of 'developed' countries to a greater extent than those 'underdeveloped' and the terms of trade of countries 'underdeveloped' worsens over time, compared to that of the developed countries (see Table 3).

\footnotetext{
1 In this paper, I made use of the terms 'Third World' and 'underdeveloped/developing/developed countries' as historical concepts, which facilitate the analysis and description, and I am not referring to their semantic correctness.
} 
Neo-Marxism and the assumption of a capitalist basis of international economic relations are the underlying philosophical bases for the theory of dependency. Injustice of the world system can be removed in different ways: some opt for an autarkic solution: gaining independence from external economic conditions, cutting off from the world economy as dominated by the needs of developed countries, and just leaving the system. Others believe that improvement can be made within the existing system.

Prebisch sees the solution to the injustice of international trade in industrialization through import subsidies. Integration of developing economies into the capitalist world economy, and focusing on trade and exports may not lead to improvement-one solution is the reduction of ties with the world economy and industrial development, leading to the independence of the processed goods produced by developed countries (Kociszewski 2011, p. 62); another solution is to move from agricultural to industrial production (Baran 1958).

Fernando Cardoso, scientist, dependency theorist and President of Brazil from 1995 to 2002, in the 1970s worked (like Prebisch) in ECLA. Cardoso, a sociologist, emphasizes the social aspect of command structures and mechanisms by which this state is maintained. However, he notes that the forms of dependence may change, because "in spite of the structural determination there is room for alternatives in history" (Cardoso and Faletto 1979, p. XI). Cardoso emphasizes in his concept that the exploitation of the periphery by the core leads to an unsustainable economic system as well within the same periphery states; as in the context of the centreperiphery relations. The development of the periphery is thus difficult and limited, which results in a form of new patterns of social (class) relations-which in turn leads to the need for redefining the state policy towards ensuring both economic stability and the possibility of articulating, and listening to the needs of society in the new situation (Tausch 2003).

According to the world-systems concept, "underdevelopment is a direct consequence of the inferior terms under which Third World economies were incorporated into the world capitalist system with this condition of inferiority maintained by the ongoing structure of that system" (Randall and Theobald 1998, p. 98). Imperialism, colonialism and neo-colonialism determined both the growth of the First World and the underdevelopment of the Third World. Researchers distinguish two or three categories of states, and the division is based on the existence of the capitalist system: metropolises and satellites as in the dependency theory (Andre Frank) and centres (core), semi-peripheries and peripheries as in the world-systems analysis (Immanuel Wallerstein).

Andre Gunder Frank, professor of sociology and economics, working at universities in North America, South America, and Europe, is a researcher significant for both the theory of dependency and the world-systems concept. ${ }^{2}$ In 1964 he published CAPITALISM AND UNDERDEVELOPMENT IN LATIN AMERICA. In the 1970s he was-like Prebisch-not only an economic theorist, but also a practitioner, as an advisor to the president of Chile, Salvador Allende. According to Frank, unequal exchange between metropolises and satellites has led to the existence of a surplus

\footnotetext{
2 Or, rather, as he preferred the world-systems theory (in the singular).
} 
(Potter et al. 1999, p. 107). ${ }^{3}$ Samir Amin, an African researcher related to the theory of dependency and world-systems concept, writes about his first meeting with Frank: "Our long conversation convinced us that we were intellectually on the same wavelength. [...]. Frank put forward a new and entirely different thesis: that from its very origins Latin America had been constructed within the framework of capitalist development as the periphery of the newly arising centres of Europe's Atlantic seaboard" (Amin 2005).

Frank graduated from the University of Chicago, from the 'forge' of the reformers in the neoclassical economics spirit, and his thesis supervisor was Milton Friedman himself. Frank has become one of the high-profile critics of neoclassical economics, the rejection to which was one of the bases for his theory. He believed that neoclassical economics not only does not apply to the economies of the South, but that even "its solutions are false". He was radical, both in his views and proposed actions, but also because he rejected orthodox Marxism, accusing it of having wrong assumptions and method of analysis (Wallerstein 2006a). In 1972, during the Congress CLASCO (Latin American Council of Social Sciences), Andre Frank, together with Cardoso, presented the basics of the dependency theory (Amin 2005). He pointed out that the dependency is expressed not only in economic relations, but that it also has far-reaching and profound ideological manifestations in the form of complexes and assimilation of the core's ideology and its attitude towards development.

Immanuel Wallerstein redefined the assumptions of the first dependency theorists, expanded the theory ${ }^{4}$ out of the previous narrow (i.e. including Latin American countries) frames, giving the concept a global dimension. According to Wallerstein, the world economy is also based on a capitalist system that is driven by the "endless desire to accumulate profits" (Wallerstein 2004b, p. 60) by the centre states ('core'), which use, for that purpose, peripheral countries as the sources of raw materials and labor force (Kegley 2006, p. 141). The centres (which have the advantage of technology and innovation) capture the surpluses produced in the developing countries and transmit the outdated technologies, whose life cycle is over, to the peripheral economies (Kociszewski 2011, p. 62).

According to the world-systems theorists, the way of defining development, the prerequisites for being a part of it and its effects are all expressions of the imbalances in the world - the strength of the standard-setting Western countries (developed countries, the Global North, centre, core) and subordination, and reproductive form of the non-Western countries (developing countries, the Global South, semiperiphery, periphery). Development, as a part of contemporary international relations, is deeply rooted in thinking about the world and its political and social structure

\footnotetext{
${ }^{3}$ Surpluses and the accumulation of capital are also the axis of Paul Baran's interest, a Marxist economist of Stanford University. Baran points out that the production of surpluses leads to the accumulation of capital and is an impulsion for economic development-but the surplus is produced by the colonized and the capital is accumulated and transformed into a tool for development by the colonizers - it's crucial to change this situation, but it can only be done through revolution, see: Vernengo 2004, p. 5.

4 Wallerstein consistently rejects the term 'theory' to describe his views. He is lobbying for rejecting such a "19th century category", he wants rather to talk about the 'thought' or simply the complex method of reality analysis.
} 
(dividing the world into 'developed' and 'developing'/'underdeveloped' countries), and has its praxeological assumptions (problem-solving attitude and focus on achieving goals, efficiency and effectiveness) originating from the Euroatlantic philosophy of action. Wolfgang Sachs - one of the most important post-development researchers-wrote "Like a towering lighthouse guiding sailors towards the coast, 'development' stood as the idea which oriented emerging nations in their journey though post-war history" (Sachs 1996, p. 1). But where is China in these frames? China's domestic development is neither associated with typical neoliberal policies (Arrighi 2007) nor does its presence in Africa fit the core-periphery pattern.

Modern international relations, shaped by division on cores, semi-peripheries and peripheries, are historically based-they result from the accumulation of capital in Europe. Geographic "discoveries," colonization and the subsequent exploitation of the colonized territories' natural resources and their transfer to Europe has led to the development of the latter (Rodney 1982). The process took place not only in the colonial period, but is also continual.

The theory of dependency was popular in the 1970s. In the 1980s, the world's largest economies entered the post-industrial era (which meant that part of the Prebisch theory became obsolete or required redefinition), and the Latin American countries were focused on debt crisis. In the 1990s the attention of economists concentrated on the problems of the transition economies after the collapse of the Eastern bloc. All of these factors led to a loss of interest in dependency theory. Nevertheless, its successors are developed to this day and they are still trying to explain why the peripheries do not become developed despite the inflow of capital and investment from the centre. Moreover, the centre gets richer at the expense of developing countries, and the gap between the majority of developing countries and the developed countries deepens. This problem is also apparent in the works of non-left-wing economists. ${ }^{5}$

\subsection{The Birth of the Washington Consensus}

"Stabilize, privatize, and liberalize" was the motto of the Washington Consensus, driving economists from the core countries, who wanted to implement neoliberal economic policies in the peripheries, to help them enter the path of development. Reforms, as codified by John Williamson, ${ }^{6}$ were introduced in Latin America,

\footnotetext{
${ }^{5}$ For instance, Economists Daniel Yergin (Pulitzer Prize winner) and Joseph Stanislaw acknowledge that as they see globalization rather positively, they don't shy away from saying that the injustices of international economic relations and the lack of an adequate (effective) system of incentives and support for developing countries is a fact, and that it can lead to re-turn from the free market. The existence of the free market is determined only by utilitarian factors: profit and prosperity, because it is not the idea or philosophy that makes people excited ("Few people would die with the words 'free markets' on their lips") (Yergin and Stanislaw 1998).

6 John Williamson, an American economist from a Washington-based think tank, called the International Monetary Fund's and the World Bank's policies towards developing countries as the "Washington Consensus". He listed the following ten elements constituting it: fiscal discipline; public spending focused on areas with high utility (health, education, infrastructure) and not on subsidies; tax reform; financial liberalization: moderate real interest rates and the abolition of preferential interest rates; competitive exchange rates; trade liberalization: the replacement of quotas by tariffs and reducing the latter in the long term; equal treatment of domestic enterprises and foreign investors (the removal of barriers); privatization; deregulation; and guarantee of property rights (Williamson 1989; Tausch 2003).
} 
Eastern Europe and Sub-Saharan Africa at different paces, but everywhere new agendas were adopted to some extent.

The Washington Consensus fits well into the world-systems framework. Both the Vietnamese failure as well as the domestic political scandal put the United States in need of revised policies to redefine its position in the changed international arena. One of the revisions made was replacing developmentalis ${ }^{7}$ with the Washington Consensus prescriptions in American economic policy towards the periphery. Its aim was to prevent (or slow down) the United States' hegemonic decline: a more profitable presence of the United States in the developing world was meant to counterbalance its weakened position with respect to its allies (Japan and Western Europe). It appeared to be a quite successful shift for the United States at least until the late 1990s (Wallerstein 2006b, p. 85).

The Washington Consensus failed as is even admitted by the World Bank: growth has not been as big as expected. The World Bank's vice-president admitted that: "there is no unique universal set of rules. [...] Sustained growth depends on key functions that need to be fulfilled overtime [...] [w] hich of these functions is the most critical at any given point in time [...] varies depending on initial conditions and the legacy of history. Thus, we need to get away from formulae and the search for elusive "best practices", and rely on deeper economic analysis to identify the binding constraints on growth" (World Bank 2005, p. xiii). It is a very strong evidence of the World Bank's self-criticism and proof that the Washington Consensus, which supported the division of the world into standard-setting cores and subjected peripheries fizzled out. No one believes in the Washington Consensus anymore but there are only a few examples of alternatives (Sachs et al. 2004; Rodrik 2006). Is the Chinese way of development one of them? As China's growth has been somehow due to its liberal economic reforms, it was still unconventional (for instance in terms of trade protection, lack of privatization, and lax financial policies) and does not fit into the Washington Consensus prescriptions. China enhanced its presence in the world economy in a different way: for instance, it established special economic zones with free-trade regimes (Rodrik 2006). Now the same is being done in Africa. ${ }^{8}$

\footnotetext{
7 Developmentalism was the dominant ideology after World War II. In order to achieve development, all of the North countries (the United States, Canada, the Soviet Union, the West European countries and the Nordic countries) offered aid and assistance (Wallerstein 2004c).

8 According to the "going global" policy in 2006, China announced the establishment of "economic and trade cooperation zones" overseas. That year, during the Forum on China-Africa Cooperation (FOCAC) meeting, the Beijing Programme for China-Africa Cooperation in Economic and Social Development was established with the aims of: know-how sharing and building and managing special economic zones (SEZs) by Chinese companies in Africa. After tenders conducted by the Chinese Ministry of Commerce (MOFCOM) in 2006 and 2007 in which many Chinese private enterprises took part, the locations of the seven future SEZs in six African countries were decided (Algeria, Egypt, Ethiopia, Mauritius, Zambia and two in Nigeria). Some of the zones were planned to be developed jointly by African and Chinese companies and others, only Chinese. SEZs are described as the "model for future collaboration between China and the continent". As for 2013, six of them were set-up in Sub-Saharan Africa: in Ethiopia, in Mauritius, two in Nigeria, and two in Zambia. SEZs generally aim at overcoming such barriers existing in domestic economy, such as restrictive policies, poor governance, lack of infrastructure and hindered access to land. However, most of the SEZs are still under construction, and some will be open soon. One of the obstacles responsible for this prolonged process is land acquisition and the related problem of land compensation for local communities (Dobronogov and Farole 2012; Giannecchini 2011; Kim 2013).
} 
The debt of the countries in Latin America (concerned particularly, but not exclusively, with the countries that introduced a policy of industrialization such as Argentina, Brazil, Chile and Mexico) has grown by leaps and bounds since the 1970s, when the international financial institutions (holding significant funds thanks to petrodollars) were giving mass granting loans on very favourable terms. At the end of the 1970s, the United States increased the dollar interest rate (in order to implement anti-inflation policy) and the value of the dollar has increased in the international market, which led, on the one hand, to the increase of interest (Eichengreen and Hausmann 1999, pp. 329-368; Vernengo 2004, p. 6) and, on the other, to the increase of the real value of the loans. That was due to the so-called 'original sin' (a term coined by Eichengreen and Hausmann), the fact that the developing countries cannot borrow in their own currencies-when the exchange rate of the international currencies changes, it always reflects on the situation of the South. Hausmann said that “(...) because of the original sin all companies will stand in front of the socalled ferris choice. They will raise funds in foreign currency and expose its balance for the currency mismatch or they will take short-term loans in the national currency risking a maturity mismatch, which can trigger liquidity crises caused by the inability to roll over the debt" (Hausmann 2001, p. 10). Combining these facts with a fall in aggregate demand in developed countries for exports from Latin America has led to the insolvency of the latter, which became apparent in 1982 when Mexico announced that its foreign reserves were depleted and the central bank could no longer service the debt. The Paris and London Clubs froze new loans and asked for the return of those given so far, which of course could not be met in the existing conditions. The bad economic situation was associated with fear of the crisis or even collapse of the entire financial system, which led to the reduction of the debt of Mexico, Costa Rica, Venezuela, Uruguay, Brazil, and Argentina in the late 1980s and in the 1990s. The reduction, however, was not unconditional; it assumed the need of general economic reforms. ${ }^{9}$ Przygodzka writes "[reforms] were not of the voluntary nature and they were not resulting from the needs and circumstances of individual countries, but they were subordinated to the development vision set out by the creditors. Today, this vision is called the Washington Consensus" (Przygodzka 2009, p. 294).

Structural adjustment programs (SAP) were introduced to help developing countries get out of the closed debt circle, which means that many countries were not even capable of paying the interest of previous loans. ${ }^{10}$ Financial institutions blamed the state-driven and public-oriented development strategies of the African countries for being unfair and ineffective, ${ }^{11}$ so they decided to change those strategies in the market-driven manner based on Western experience.

\footnotetext{
${ }^{9}$ Structural Adjustment Programs were of limited accessibility: they were subjected to several conditions, which can be summarized as liberalization of the economy, but at the same time when financial institutions demanded the African governments to stop subsidizing import industries and to open domestic markets to international competition, Western economies were subsidizing and heavily protecting its agriculture industry.

10 The service of Africa's total loans cost in 1980s and 1990s up to $20 \%$ of its export income each year (Thomson 2010, p. 194).

11 Which probably was true, concerning, for instance, buying by the African governments domestic harvests at depressed prices and then selling them on the world market at market prices.
} 
Even though financial institutions' intensions were full of goodwill (for example in the case of African farmers being paid fair, market prices for their crops), the effects of SAP are seen in an ambiguous way by different scholars (for example positive opinion about SAP in Africa in the World Bank in 1994; while negative in: UNECA 1989). In this context, words written in 1994: "By embracing structural adjustment, Africa is now taking the crucial first step in creating a favourable economic environment for sustainable growth and development" (World Bank 1994, p. 220) may be now seen as unproven.

The economic impact of SAP was different in each country. The economic indicators in some of them improved; in others, deteriorated (World Bank 1994, pp. 222-258). For sure, one of its results was putting a focus on exporting agricultural and other primary products, which had to finish in decreasing world prices for those commodities, as their supply in the world market increased.

On the other hand, the social impact of SAP is seen in a more one-dimensional way: it resulted in bigger unemployment rates, cuts in public sector spending (of course it should be remembered that public spending and employment rates in administrations before SAP were excessively high) and the former had negative impacts: on education (in some cases, previously free education now required a fee) and on food prices (government food subsidies were cut off). It was only in the late 1980s when the World Bank leaned over the social consequences of SAP and put more effort on combating them. From 1980 to 2005, the total debt in the developing economies in Africa increased by $160 \%$ with a concurrent large increase in debt service costs. It was only in 2010 when this sum dropped that made possible increasing disbursement rate, so that net transfers on debt became positive (see Table 1).

The social impacts of SAP resulted in dissatisfaction of the Africans, which obviously altered their attitude towards national governments, seen as responsible for the negative changes and blamed for no longer providing client-patron relations, which hitherto was a base of the post-colonial society-government mode of living (Thomson 2010, p. 202; N'Dione 1994; N'Dione et al. 1997, pp. 364-376; Appiah 2008, pp. 115-117).

\section{Is the World-Systems Concept Applicable to the Current Engagement of China in Africa?}

I think that the argument about the lack of applicability of the dependency and world-systems perspective as a whole is misplaced. Unequal participation in the global economy and the consequent division of the world into centre states (the beneficiaries of the system) and semi-peripheries/peripheries is a reality, but in the current circumstances (regarding the economic growth of South East Asia, China and India), it may require reinterpretation.

The fact that the PRC is considered a developing country may be seen as controversial, but within the United Nations system, clear separation between 'developed' and 'developing' states has not yet been defined. The closest hint to catch the essence of the concepts was given by Kofi Annan, who described the 
Table 1 Total external long-term debt in developing economies in Africa (USD millions, 1980-2010; UNCTAD 2012)

\begin{tabular}{lrrrrr}
\hline & 1980 & \multicolumn{1}{c}{1990} & \multicolumn{1}{c}{2000} & \multicolumn{1}{c}{2005} & \multicolumn{1}{c}{2010} \\
\hline Debt outstanding $^{1}$ & 90,299 & 235,385 & 250,363 & 251,394 & 235,903 \\
Disbursements $^{\mathrm{a}}$ & 19,421 & 21,528 & 14,550 & 23,691 & 33,402 \\
Debt service $^{\mathrm{b}}$ & 11,561 & 23,034 & 22,271 & 30,770 & 21,441 \\
Principal repayments $^{\text {Interest payment }}$ & 6,512 & 14,680 & 15,337 & 20,688 & 15,475 \\
Net transfers on debt $^{\mathrm{c}}$ & 5,049 & 8,354 & 6,934 & 10,082 & 5,966 \\
\hline
\end{tabular}

Long-term debt is defined by UNCTAD as debt that "has an original or extended maturity of more than one year and that is owed to nonresidents and repayable in foreign currency, goods, or services"

a Disbursements on long-term debt are defined by UNCTAD as "drawings on loan commitments during the year specified"

${ }^{\mathrm{b}}$ Long-term debt service payments are defined by UNCTAD as "the sum of principal repayments and interest payments in the year specified"

${ }^{c}$ Net transfers on long-term debt are defined by UNCTAD as 'disbursements' minus 'debt service payments'

developed state as such that "allows its citizens to enjoy a free and healthy life in a safe environment". Given a contrario, it appears likely that in developing countries such a possibility of a free, healthy and safe life for its citizens cannot be guaranteed. According to the World Bank, countries with GNI per capita in $2012^{12}$ of less than 12,615 USD may be called the developing ones. ${ }^{13}$ According to World Bank's data, the rate for the PRC amounted to 9,210 USD in 2012. What is more, the World Bank notes that "the use of the term [developing economy] is convenient; it is not intended to imply that all economies in the group are experiencing similar development or other economies have reached a preferred or final stage of development. Classification by income does not necessarily reflect development status"[!] (World Bank 2013). The group of developing countries is very diverse and the difference between Brazil, India, Russia, and China and other countries of Southeast Asia, Africa or Latin America can be intuitively seen. To distinguish those different categories, the term 'the newly industrialized' countries was created, which include most often, despite the absence of a valid methodology - in addition to the above mentioned (except for Russia)-Malaysia, Mexico, Philippines, South Africa, Thailand, and Turkey.

In Polish science, some authors also use the world-systems categories when writing about new global powers. Karin Tomala admits: “as a result of China's economic development - in the last 30 years on average by $12 \%$-the country changed its status from a peripheral to a centre state” (Tomala 2012, p. 14). In addition, the author notes that the financial crisis in 2008 has led to a change of tone in the debate on development, in seeking alternatives to "prescriptions of the West,

\footnotetext{
12 Those numbers are set on July 1 st each year.

13 But as the World Bank writes on its website: "Low-income and middle-income economies are sometimes referred to as developing economies."
} 
where neoliberal ideology of industrialized countries dominated so far" (Tomala 2012, p. 20).

The actuality of the world-systems concept can be seen in the obvious examples of not only the division of labour (and not just in cheap manpower in Asia, producing goods for corporations with dominant Western capital, but also in the outsourcing of manpower: in the so-called 'shared-service centres', using specialists based in India, for instance), but also in the use of raw materials of the Global South countries (Sub-Saharan Africa, Latin America and Asia) for core states, or for other developing countries (e.g. China).

China's presence in the developing countries of Africa (as well as Latin America and Asia) is a theme quite popular in science, especially after 2000, when the Forum on China-Africa Cooperation (FOCAC) was established. The milestone, also due to the beginning of mass interest in the topic of Sino-African cooperation from the media and world public opinion, was the FOCAC summit in Beijing in 2006, held under the banner of the 50th anniversary of Sino-African relations. This 'going global' policy was also underlined during the 15th Communist Party of China Congress, when FDI were accepted as a key point for maintaining energy security for economy, internationalization of Chinese companies and keeping a competitive advantage (Mierzejewski 2012, p. 61).

China does not hesitate to defend the interests of developing countries, as during the United Nations General Assembly in 2005, Hu Jintao presented his vision of " $a$ harmonious world with long-lasting peace and common prosperity". In this vision, he not only called for accelerating the growth of developing nations and respecting the right of choosing development paths, but also asked for the reform of the Security Council in the way of giving "more consideration to the representation of the developing countries, especially the African nations" (Jintao 2005). This is in accordance with the philosophical base of China's foreign policy. However, there are a few Chinese scholars, who admit that the faith in creating a calm, peaceful image of China is not fully consistent with the reality, because Confucian morality, being the basis for authority, requires talking about mistakes made by developed countries towards developing ones and leads to stressing the need of building a new relationship on the basis of justice and equal rights (Mierzejewski 2012, pp. 64-79).

\subsection{China-Africa Relations and the Traditional Assumptions of World-Systems Concept}

The economic crisis touched the developed economies, which are still the major players in the world economy and trade even though their share in total trade declined to $55 \%$ in 2010 (that means a decline of $14 \%$ in 15 years). Of course, it rebounded also on the developing economies, as import demand from developed countries diminished, but as the UNCTAD notes: "increased South-South trade has partly counterbalanced this deceleration" (UNCTAD 2012, p. 6). In most developing economies, the volume of exports highly decreased during the crisis (especially in Latin America; see Table 2).

Nevertheless, historically Africa's situation in terms of trade consequently worsened, also indicating that the development of economic policy as seen by 
financial institutions hadn't hd expected effects (of course we can identify multiple reasons for worsening terms of trade at that time, from which the oil crisis in the 1970s is probably the most notable). ${ }^{14}$

Chinese import from Sub-Saharan Africa is based on resources, while its export is dominated by processed products. This leads, on the one hand, to the short-sighted and not very favourable structure of the trade of African countries, ${ }^{15}$ and, on the other hand, to accusations of China's neo-colonial tendencies. However, the advantages of the extension of Africa's trading partners' portfolio should not be forgotten: as research shows, developing countries with higher numbers of partners in international trade experience greater economic growth than those with limited numbers of partners (Clark 2008, p. 639). Jean-Claude Maswana, an economist at the University of Kyoto compared Sino-African relations and the assumptions of the world-systems concept. Although the study is quite one-sided, however, it reveals some elements worth further analysis and testing.

China's growth coincides with the improvement of Africa's terms of trade, which is inconsistent with the Prebisch-Singer thesis. Of course it is also a fact that the import of cheap Chinese goods (especially textiles) is a real threat to local manufacturers in Africa. The fact that Chinese companies employ their own citizens while investing in Africa must be seen as negative in terms of transfer of technology, skills and knowledge, and of course in terms of possible unemployment in Africa.

A key aspect of China's development model is focused on building economic relations, while respecting the principle of non-interference in internal affairs ${ }^{16}$ and respecting cultural differences (Blazquez-Lidoy et al. 2004). The non-interference principle certainly does not correspond to the traditional way of controlling the peripheries. The difference of the Chinese development model from the Western development model should be emphasized. Karin Tomala writes: "Growing China can be described as a biggest laboratory in the world, where everything is changing-and it's changing not with accordance with Western dogmas or theoretical systems, but on the basis of experiments, which gained increasing popularity because of being successful. For the Western world it is not always easy to understand and clearly outrageous" (Tomala 2012, p. 18).

It is worth noting that China is beginning to emphasize the importance of the social factor in its long-term vision of development, which will lead to a specific, Chinese model of development (Fulin 2010, p. 6). China wants to follow its own path built on Chinese traditions, on 'win-win' cooperation and on multilateralism rather than hegemony. This model seems interesting for other developing countries, because it "provides a wider field of action" (Tomala 2012, p. 43).

\footnotetext{
14 The consequences of the oil crisis can be seen in two dimensions: on the one hand-as was stated in BERG REPORT - in the $1970 \mathrm{~s}$ African countries spent $\sim 1 \%$ of their GDP on oil imports, in the 1980s it increased to $\sim 6 \%$, on the other-Western financial institutions gained petrodollars from OPEC countries, which were then loaned to African countries (World Bank 1981).

15 However, this kind of African trade structure hasn't changed since colonial times. As Basil Davidson notes:,to 1929 cotton made $80 \%$ of Uganda's exports, cacao-79\% of the Gold Coast's exports, cloves-61\% of Zanzibar's exports, so the colonies were one-crop producers providing commodities for colonial powers (Davidson 2011, p. 60).

16 What is sometimes, as in the case of Sudan, controversial. China follows the principle of nonintervention in internal affairs but weapons manufactured in China were used in Darfur, despite the ban on trade in arms with al-Bashir's regime.
} 
Table 2 Export and import volumes of goods, selected regions and countries, 2008-2011 (annual percentage change; UNCTAD 2012)

\begin{tabular}{|c|c|c|c|c|c|c|c|c|}
\hline \multirow[t]{2}{*}{ Region/country } & \multicolumn{4}{|c|}{ Volume of export } & \multicolumn{4}{|c|}{ Volume of import } \\
\hline & 2008 & 2009 & 2010 & 2011 & 2008 & 2009 & 2010 & 2011 \\
\hline World & 2.4 & -13.1 & 13.9 & 5.9 & 2.5 & -13.4 & 14.1 & 5.0 \\
\hline Developed countries & 2.5 & -15.2 & 13.2 & 5.1 & -0.2 & -14.5 & 11.0 & 3.5 \\
\hline Developing countries & 3.2 & -9.7 & 15.4 & 7.0 & 6.6 & -9.9 & 19.2 & 6.2 \\
\hline Africa & -3.1 & -9.7 & 8.7 & -5.1 & 10.6 & -3.9 & 7.1 & 3.9 \\
\hline Sub-Saharan Africa & -4.1 & -8.0 & 10.2 & 2.9 & 3.2 & -4.4 & 8.8 & 7.0 \\
\hline Latin America and Caribbean & -0.3 & -11.0 & 10.3 & 3.4 & 8.5 & -17.9 & 23.3 & 7.1 \\
\hline East Asia & 7.3 & -10.6 & 23.8 & 9.9 & 0.4 & -5.3 & 25.0 & 7.5 \\
\hline China & 10.6 & -13.9 & 29.0 & 12.8 & 2.3 & -1.8 & 30.8 & 10.6 \\
\hline South Asia & 6.8 & -6.0 & 6.0 & 9.1 & 20.9 & -5.6 & 13.9 & $4.1^{\mathrm{a}}$ \\
\hline India & 16.8 & -6.6 & 5.9 & 13.7 & 29.7 & -0.8 & 13.8 & 5.3 \\
\hline South-East Asia & 1.6 & -10.9 & 18.8 & 4.5 & 8.0 & -16.3 & 21.9 & 6.1 \\
\hline West Asia & 4.4 & -1.1 & 2.6 & 12.7 & 12.5 & -11.5 & 5.4 & 3.8 \\
\hline
\end{tabular}

a "South Asia and West Asia have been the exceptions, as their exports actually accelerated in 2011, but this is somewhat misleading, as this increase was from low levels in 2010 when some large economies in these regions, such as India and Turkey, failed to bounce back above the levels they had registered in 2008" (UNCTAD 2012)

\subsection{Is the Beijing Consensus Really an Alternative to the Washington Consensus?}

Some scientists are wary of using the term "the Beijing Consensus" as applicable to the vision being promoted by China (as a counterbalance to the influence of the Washington Consensus), but at the same time, they admit that it gained popularity in the Global South (Schweller and Pu 2011, p. 61). Beijing's model of development (unlike Washington's) does not want to be imposed, but it is just appealing, because of the evident Chinese success story (Xinbo 2010, p. 159).

The author of this term, Joshua Cooper Ramo, assumes that China's growing importance has not only changed the international order but has also created a new model on which other nations can build their own development. He assumes that the Chinese path of transformation is tempting for the whole world "who are trying to figure out not simply how to develop their countries, but also how to fit into the international order in a way that allows them to be truly independent, to protect their way of life and political choices." Ramo believes that the Beijing Consensus replaces the Washington Consensus, which he calls "the widely-discredited [...] Washington-knows-best approach to telling other nations how to run themselves" and "a hallmark of end-of-history arrogance." The Beijing Consensus can be described with words such as peaceful, innovative, pragmatic but also ideological, growth-oriented, asymmetric power tools-based, national and flexible (not believing in universal solutions). It foresees gradual changes, not shock-therapies; it assumes that social change is as important as economic change (Ramo 2004, p. 2-4). 


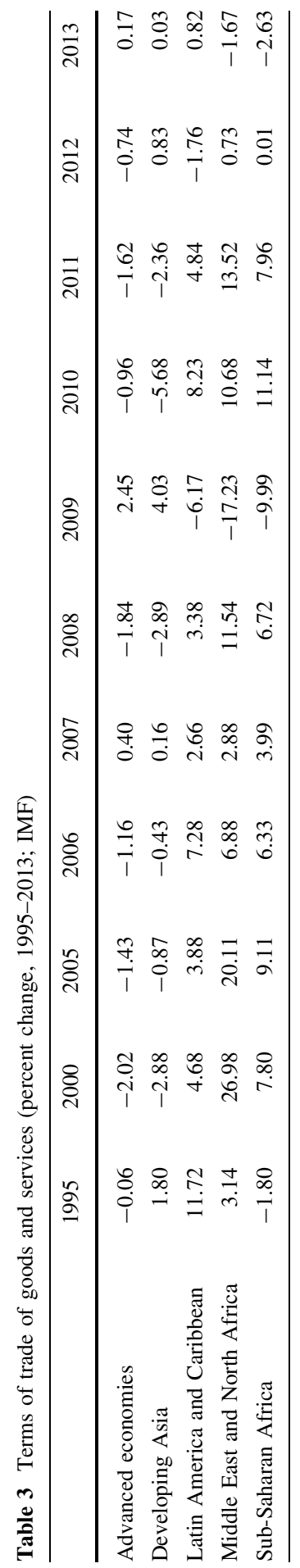


Table 4 China-Africa relations and the traditional assumptions of world-systems concept (Maswana 2007)

\begin{tabular}{|c|c|c|c|}
\hline & Aspect & $\begin{array}{l}\text { Traditional world-systems } \\
\text { concept }\end{array}$ & China-Africa relations \\
\hline 1 & $\begin{array}{l}\text { The structure of African } \\
\text { exports and terms of trade }\end{array}$ & $\begin{array}{l}\text { Exports of raw materials/import } \\
\text { of capital goods TT (-) }\end{array}$ & $\begin{array}{l}\text { Exports of raw materials/import } \\
\text { of capital goods TT }(+)\end{array}$ \\
\hline 2 & Investments & $\begin{array}{l}\text { Carried out mostly by private } \\
\text { companies }\end{array}$ & $\begin{array}{l}\text { Carried out mainly by state- } \\
\text { owned enterprises }\end{array}$ \\
\hline 3 & Type of cooperation & $\begin{array}{l}\text { North-South (inequality, } \\
\text { subordination }\end{array}$ & $\begin{array}{l}\text { South-South (equality, } \\
\text { partnership, reciprocity) }\end{array}$ \\
\hline 4 & Technology and labour & Limited in-house training & No significant training \\
\hline 5 & $\begin{array}{l}\text { Superstructure (political)/ } \\
\text { ideology (elite) }\end{array}$ & Restrictions, conditional & $\begin{array}{l}\text { Focus on the similarities, } \\
\text { unconditional }\end{array}$ \\
\hline 6 & $\begin{array}{l}\text { The dominance of the } \\
\text { financial and monetary }\end{array}$ & High (dollarization) & Low \\
\hline 7 & $\begin{array}{l}\text { The perception of the African } \\
\text { market }\end{array}$ & $\begin{array}{l}\text { No significant economic } \\
\text { importance }\end{array}$ & As a potential market \\
\hline
\end{tabular}

The Beijing Consensus is the new model of describing the role of a developing state and consists of three main points. First, the value of innovation is emphasized. It assumes that constant changes in the search for the optimum are necessary, so that the possibility of failure is a natural consequence and should be taken into account. Second, the necessity of chaos management in a rapidly changing society, when the focus of development has changed from growth-oriented to people-driven, is underlined. Third, the self-determination is crucial: China is still underlining that it has its own problems, and that it is still a developing country, and it does not want to dominate. China's will is only to determine its own path.

It is worth asking why the way China develops became attractive to the peripheries. That is because of China's "kinetic energy of recoil" in times when the Washington Consensus failed. Furthermore, China's pride of its own culture becomes a model to follow: the Beijing Consensus gives another path to globalization-a path where localness and local suitability are of primary importance. China is also no longer so US-focused in its foreign policy: it figured out that what should count the most now-in order to keep growing - it is to have a stable local environment thanks to its "Good Neighbourliness" policy (as a part of the New Security Concept). The visible point of this new policy is, for example, creating the Shanghai Cooperation Organization (SCO) (Ramo 2004, p. 52).

The Beijing Consensus as seen by Ramo can be summarized as "a new route towards development that is based on innovation, asymmetry, human-up development and a focus on the balance of individual rights and responsibilities" (Ramo 2004, p. 55).

\section{Conclusion}

Can the current unprecedented presence of China in Sub-Saharan Africa (as well as in other regions of the Global South) be viewed as a part of the world-systems concept? China, described by Wallerstein as a semi-periphery is no longer a link 
between the periphery and the centre; it plays a different role. It is only after 2000 (see Table 3) when the terms of trade of African and Latin American economies improved. It is also the time of intensifying relations of these regions with China. However, it may not be concluded that it was the main or even one of the reasons, but it should challenge the thinking about China as the provider of a new model of contemporary international relations. China is building its relations with the developing world on a new basis, different from that on which the Western countries used to build. It may result from: the Confucianism philosophy which is a base for authorities' morality, economic and political calculation (paying attention to internal growth and doing the proper things to maintain it), or even from learning from Western countries' mistakes (Table 4).

However, the Beijing Consensus is not a model in the strictest sense of the word, i.e. it does not provide simple prescriptions as the Washington Consensus does. The latter gives ten explicit rules, the former three of which are less tangible concepts, so it may seem to be less useful as a research tool. However, the lack of straight prescriptions does not mean that the Beijing Consensus does not give us a framework within which we can try to see the future of the peripheries. Nevertheless, it seems that the use of the term "consensus" to describe China's path of development is rather exaggerated.

The World-systems theory could be considered in conjunction with the Washington Consensus as the means of imposing hegemony by the core to the semi-periphery and periphery. The Chinese model, apart from whether rightly or wrongly called the "Beijing Consensus," does not fit the theory's framework easily. China is a semiperiphery in terms of Wallerstein's theory as it is semi-industrialized, still has a lot of domestic problems (e.g. poverty), and has an above-average market. However, semiperiphery countries do not have the power in terms of economic and political influence of core nations. The reality seems to be different. China is a growing power and it tramples on heels of the core countries. The Chinese model, however not being imposed, seems to be tempting for the peripheries. The World-systems theory does not develop the concept of peripheries being driven by semi-peripheries to the road of economic success (or following the distinct model of semi-peripheries). But it also does not exclude it. Thus, it seems that the world-systems theory should be expanded if it is to fulfil its main assumption, i.e. be consistent with the reality of international relations. The Beijing Consensus can be a useful tool for identifying different (from the Washington Consensus driven core-periphery relations) models of cooperation in the international arena.

Open Access This article is distributed under the terms of the Creative Commons Attribution License which permits any use, distribution, and reproduction in any medium, provided the original author(s) and the source are credited.

\section{References}

Amin, S. 2005. A note on the death of Andre Gunder Frank (1929-2005). Monthly Review 57(2): 1.

Appiah, K.A. 2008. Kosmopolityzm. Etyka w świecie obcych. Warsaw: Prószyński i S-ka. Arrighi, G. 2007. Adam Smith in Beijing: Lineages of the twenty-first century. London: Verso. Baran, P. 1958. The political economy of growth. New York: Monthly Review Press. 
BBC. 2011. China's Stake in Zambia's Election. http://www.bbc.co.uk/news/world-africa-14952240. Accessed 30 Dec 2013.

Blazquez-Lidoy, J., J. Rodriguez, and J. Santiso. 2004. Angel or devil? Chinese trade impact on Latin American emerging markets. Washington DC: Center for Latin American University of Georgetown University.

Broad, R., and J. Cavanagh. 1999. The death of the Washington consensus? World Policy Journal 16(3): 79.

Cardoso, F.H., and E. Faletto. 1979. Dependency and development in Latin America. Berkeley: University of California Press.

Clark, R. 2008. Dependency, network integration and development. Sociological Perspectives 51(3): 629448.

Davidson, B. 2011. Społeczna i polityczna historia Afryki w XX wieku. Warsaw: Wydawnictwo Naukowe PWN.

Dobronogov, A., and T. Farole. 2012. An economic integration zone for the East African Community. Exploiting regional potential and addressing commitment challenges. Tshwane: World Bank.

Eichengreen, B., and R. Hausmann. 1999. Exchange rates and financial fragility. New challenges for monetary policy. Kansas City: Federal Reserve Bank of Kansas City.

Ferraro, V. 2008. Dependency theory: An introduction. In The development economics reader, ed. Giorgio Secondi. London: Routledge.

Fulin, C. (ed.). 2010. Change of China. Development models at the crossroads. Beijing: Zhongguo Pianbian Tushuguan.

Giannecchini, P. 2011. China's special economic zones: A bright future for Africa? The China Monitor 65: 7-9.

Hausmann, R. 2001. Polska droga do euro: Ameryka Łacińska patrzy z zazdrością, paper prepared for the conference "Polish road to the Euro" organized by the Polish National Bank, Warsaw, October $22-23$.

Hryniewicz, J. 2010. Teoria “Centrum-Peryferie" W Epoce Globalizacji. Studia Regionalne i Lokalne 40(2): 5-27.

Jintao, H. 2005. Making Great Efforts to Build a Harmonious World with Long-lasting Peace and Common Prosperity, speech during plenary session of United Nations General Assembly, September.

Kegley, ChW. 2006. World politics: Trend and transformation. Wadsworth: Cengage Learning.

Kim, Y. 2013. Chinese-led SEZs in Africa are. They a driving force of China's soft power?. Stellenbosch: Yejoo Kim.

Kociszewski, J. 2011. Paradygmaty Rozwoju Współczesnej Gospodarki Światowej Na Przykładzie Krajów Biednych. Nierówności Społeczne A Wzrost Gospodarczy 18: 1. Rzeszów.

Maswana, J. C. 2007. China-Africa's Emerging Economic Links: A review under the Core-Periphery perspective. In Proceeding for the Annual Conference of the World Association for the Political Economy (WAPE), October 27-28 2007, Shimane, Japan.

Mierzejewski, D. 2012. Spory o miejsce i rolę Chin w stosunkach międzynarodowych. Dziak, W., Gawlikowski, K., and Ławacz M. (eds). Chiny w XXI wieku. Perspektywy rozwoju. Warsaw: Instytut Studiów Politycznych Polskiej Akademii Nauk.

N'Dione, E. 1994. Reinventer le present. Quelques jalons pour l'action. Dakar: ENDA/GRAF.

N'Dione, E., P. De Leener, and J. Perier. 1997. Reinventing the present: The Chodak experience in Senegal. In The post-development reader, ed. M. Rahnema, and V. Bawntree. Cape Town: David Philip.

Potter, R., T. Binns, J. Elliott, and D.M. Smith. 1999. Geographies of development. London: Longman.

Przygodzka, R. 2009. Kryzysy w Ameryce Łacińskiej. In Od wielkiego kryzysu gospodarczego do wielkiego kryzysu finansowego. Perturbacje $w$ gospodarce światowej $w$ latach 1929-2009, ed. J. Kaliński, and M. Zalesko. Białystok: Wydawnictwo Uniwersytetu w Białymstoku.

Ramo, J.C. 2004. The Beijing consensus, notes on the new physics of Chinese power. London: Foreign Policy Centre.

Randall, V., and R. Theobald. 1998. Political change and underdevelopment: A critical introduction to third world politics. Durham: Duke University Press.

Rodrik, D. 2006. Goodbye Washington consensus, hello Washington confusion? A review of the world bank's economic growth in the 1990s: Learning from a decade of reform. Journal of Economic Literature XLIV: 973-987.

Rodney, W. 1982. How Europe underdeveloped Africa. Washington, D.C: Howard University Press. 
Sachs, J.D., et al. 2004. Ending Africa's poverty trap. Brookings Papers on Economic Activity 1: $117-240$.

Sachs, W. 1996. The development dictionary: A guide to knowledge as power. London and New Jersey: Zed Books.

Schweller, R.L., and X. Pu. 2011. After unipolarity: China's visions of international order in an era of U.S. decline. International Security 36(1): 41-72.

So, A.Y. 1990. Social change and development: Modernization, dependency and world-system. London: Sage Publications.

Tausch, A. 2003. Social cohesion, sustainable development and Turkey's accession to the European union: Implications from a global model alternatives. Turkish Journal of International Relations 2(1): $1-41$.

Thomson, A. 2010. An introduction to African politics, 3rd ed. London: Routledge.

Tomala, K. 2012. Zmieniające się miejsce Chin w świecie. Czy dominacja Zachodu skończy się w XXI wieku? In Chiny w XXI wieku. Perspektywy rozwoju, ed. W. Dziak, K. Gawlikowski, and M. Ławacz. Warsaw: Instytut Studiów Politycznych Polskiej Akademii Nauk.

UNCTAD. 2012. Trade and Development Report. 2012. Policies for Inclusive and Balanced Growth. United Nations Conference on Trade and Development.

UNECA. 1989. African Alternative Framework to Structural Adjustment Programmes for SocioEconomic Recovery and Transformation. United Nations Economic Commission on Africa.

Vernengo, M. 2004. Technology, Finance and Dependency: Latin American Radical Political Economy in Retrospect. Working Paper No: 2004-2006, University of Utah Department of Economics.

Wallerstein, I. 2004a. Koniec świata jaki znamy. Warsaw: Scholar.

Wallerstein, I. 2004b. World-systems analysis: An introduction. Wallerstein: Duke University Press.

Wallerstein, I. 2004c. After developmentalism and globalization. what? Address at conference, Development Challenges for the 21st Century, Cornell University, October 1.

Wallerstein, I. 2006a. Remembering Andre Gunder Frank. History Workshop Journal 61: 305.

Wallerstein, I. 2006b. The curve of American power. New Left Review 40: 77.

Wallerstein, I. 2010. Shall We Discuss Poverty? Commentary No. 294. Fernand Braudel Center, Binghamton University, December 1.

Washington Post. 2009. A conversation with John Williamson, economist. Washington Post. Sunday, April 12.

Williamson, J. 1989. What Washington means by policy reform. In Latin American readjustment: How much has happened, ed. J. Williamson. Washington: Institute for International Economics.

World Bank. 1981. Accelerated development in Sub-Saharan Africa: An agenda for action (The Berg Report).

World Bank. 1994. Adjustment in Africa: Reform, results and the road ahead.

World Bank. 2005. Economic growth in the 1990s: Learning from a decade of reform. Washington, D.C.: World Bank.

Xinbo, W. 2010. Understanding the geopolitical implications of the global financial crisis. Washington Quarterly 33(4): 103.

Yergin, D., and J. Stanislaw. 1998. The commanding heights: The battle for the world economy. New York: Free Press.

Ewelina Lubieniecka is a Ph.D. candidate in the Institute of International Relations, University of Warsaw Poland. In 2013, she was awarded with Chinese Government Scholarship to study at Xiamen University, China. In 2014, she was awarded with IPRS and APA Scholarship to study at University of Melbourne. Her research focuses on Sub-Saharan economic policies. 